\title{
焼結/熱間押出し複合加工で製造した黒鉛粒子分散 $\mathrm{Al}-\mathrm{Si}$ 合金の摩耗特性
}

\author{
湯 浅栄二* 師 岡利政* 葉山房夫** \\ J.Japan Inst.Metals, Vol.52,No.2(1988),pp.163-170
}

Wear Characteristics of Graphite-dispersed Al-Si Alloy Prepared by the Combined Process of Sintering and Hot Extrusion

Eiji Yuasa*, Toshimasa Morooka* and Fusao Hayama**

Graphite-dispersed Al-Si alloys were prepared by the combined process of sintering and hot extrusion (sintering/hot-extruding process). The wear characteristics of the products were examined at various sliding speeds and compared with those of sand castings of $\mathrm{Al}-\mathrm{Si}$ alloys (casting process) and of the graphite-dispersed Al-Si alloys prepared by re-melting and freezing in a quartz tube after extruding the mixture of aluminum, silicon and graphite powders (re-melting process). Effects of the matrix structure and graphite particles on the wear characteristics of these graphite-dispersed alloys were discussed. In the sintering/hotextruding process the values of wear rates of these alloys with the matrix phase of fine eutectic structure were extremely small in the range of low sliding speeds. In all the alloys the wear rates increased with increasing sliding speed and then attained a peak value. The increment of the wear rate in this range of sliding speeds decreased with increasing silicon content in the matrix phase and with increasing volume fraction of the graphite particles. With a further increase of the sliding speed, the wear rate decreased and attained a small value. However, the contents of silicon and graphite in these alloys exerted a negligible effect on the decrement of the wear rate. When the alloy having a soft matrix phase as with a low silicon content was rubbed in the range of high sliding speeds, the wear rate showed a low value, but it was remarkably increased by adhesion to a counterface as the sliding speed increased.

(Received July 6, 1987)

Keywords: particle-dispersed composite, aluminum-silicon alloy, graphite particle, solid lubricant, liquid-phase sintering, hot-extrusion, wear rate, sliding speed

\section{I 。緒言}

著者らは，乙れまでの研究でアルミニウムおよび Al-Si 合金を素地とする黒鉛粒子分散合金を粉末押出し法によっ て製造し(1)，その摩耗特性について調べた ${ }^{(2)(3)}$. その結果， アルミニウムを素地とする合金では，低すべり速度のとき， 黒鉛が真実接触部のと乙ろの prow の生成，成長を抑制 して低比摩耗量となる。しかし，高すべり速度になると素 地の塑性変形が大きくなるので, 耐荷重性の大きい Al-Si 合金の方が黒鉛分散効果が高く, 比摩耗量が低くなること を明らかにした。ただし, 珪素粒子が粗大であると, prow は大きく成長し，黒鉛や珪素粒子とともに脱落して比摩耗
量が大きくなる．したがって，素地の珪素粒子は鋳物の共晶 珪素相程度に細かくする必要があった. Rohatgi ら (4)(5) は, Al-Si 系実用合金の溶湯を撹はんして黒鉛粒子を分 散させる方法によって合金を製造した。そしてその摩耗特 性を乾燥および潤滑摩擦下で調へ(6)(7)，黒鉛粒子の潤滑効 果により，その合金の耐摩耗性が向上することを見いだし ている.諏訪ら ${ }^{(8)}$ あ同様な結果を得ているが，乙れらの合 金は，黒鉛粒子のアルミニウム溶湯に対する姓改善の ために，粒子表面に施したニッケルや銅メッキが製造過程 で溶出して素地組成が変化し, 素地の耐焼付き性を低下さ せることが指摘されている(9)(10).

アルミニウム粉, 珪素粉抢よび黒鉛粉の混合圧粉体を, 素地に Al-Si 共晶融液が生成するような押出し温度で液

* 武蔵工業大学工学部機械工学科(Department of Mecanical Engineering, Faculty of Engineering, Musashi Institute of Technology, Tokyo)

** 早稲田大学理工学部, 現在: 早稲田大学名誉教授(Faculty of Science and Engineering, Waseda University, Tokyo. Present situation : Emeritus Professor of Waseda University) 
相焼結しつつ熱間押出しすれば，Al-Si 共晶組織を有す る素地に黒鉛粒子が分散する合金を製造するてとができ る(11). その上，乙の合金の素地の珪素相は非常に微細で， かつ押出し方向に配列して, 合金の押出し方向の機械的強 度む高い。そこで本報はこのような焼結/熱間押出し法で 製造した黒鉛分散合金の摩耗特性を調べ，通常の砂型およ び金型鋳物あるいは粉末押出し後, 再溶解して素地を鋳造 組織とした黒鉛分散合金と比較し，合金の摩耗特性に及ぼ す黒鉛粒子および素地組織の影響について検討した。

\section{II. 実 験 方 法}

実験に用いた粉末は市販の純度 99.78 mass \% の噴霧了 ルミニウム粉(粒径 $105 \mu \mathrm{m}$ 以下) と純度 99.99 mass\% の 鋳塊を粉砕した珪素粉(粒径 74〜210 $\mu \mathrm{m}$ ) である.乙れら を Al- 4 mass $\% \mathrm{Si}, \mathrm{Al}-12$ mass\% Si, Al- 22 mass\% Si のそれぞれ亜共晶, 共晶, 過共晶組成となるように混合し, 素地材料とした。黒鉛は炭素分 99.0 mass\% の市販の天

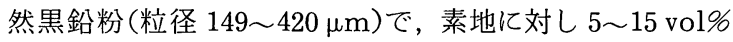
を混合した．乙れを計算密度の $80 \%$ まで圧粉し，純度 99.8 mass\%のアルミニウム缶に入れ，素地に液相が生成する 温度で焼結しつつ，熱間押出しして合金を製造した。その 製造条件および方法は既報 ${ }^{(11)}$ と同様である.

比較のための再溶解した合金は，黒鉛を混合した圧粉体 を $773 \mathrm{~K}$ で粉末押出しし, 押出し棒を面削後, その直径 之同じ内径の石英管に入れ，電気炉中で，素地成分の液相 線より約 $150 \mathrm{~K}$ 高い温度で溶解し，そのまま空冷，凝固 して得た．Fig.1は，Al-22 mass\% Si 素地に 10 vol\%

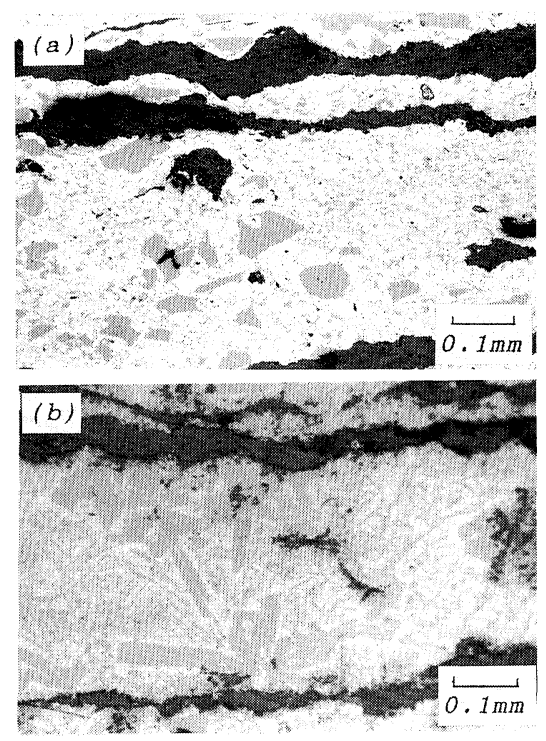

Fig.1 Optical micrographs of longitudinal section in $\mathrm{Al}-22$ mass $\% \mathrm{Si}$ alloy containing dispersed 10 vol\% graphite (a) prepared by the sintering/hotextruding process and (b) by the re-melting process.
黒鉛が分散する合金を焼結/熱間押出しおよび粉末押出し 後再溶解して製造し，それぞれの合金の押出し軸方向に平 行な断面の光顕組織を示す. 焼結/熱間押出しした合金の 共晶珪素相は細い粒状あるいは針状になって, 押出し方向 に配列しているが，すべてが溶解するてとなく，残量となっ た粗大な粒子あある.黒鉛粒子は押出し過程で素地の流動 にともなって伸長され, 押出し方向に短繊維状に配列して いる．再溶解合金の素地組織は通常の砂型鋳物と同様であ るが，黒鉛は粉末押出し時に伸長された粒子がそのままの 形状を維持している. てれらの押出し棒より, 軸方向に対 し, 種々の方向に, $6 \mathrm{~mm} \times 6 \mathrm{~mm}$ の摩擦面となるような 摩耗試験片を作製した。また純度 $99.98 \mathrm{mass} \% \mathrm{Al}$ 地金と Al-25.36 mass $\% \mathrm{Si}$ 母合金を用い, Al-4 mass $\% \mathrm{Si}, \mathrm{Al}-$ 12 mass\% Si, Al-22 mass\% Si に配合して黒鉛るつぼ中 で大気溶解し, 直径 $25 \mathrm{~mm}$, 長さ約 $300 \mathrm{~mm}$ の金型およ び砂型に鋳込み，Al-Si 合金鋳物を作製した.乙れを形 削りし, 鋳塊のほぼ中心部より長手方向に $6 \mathrm{~mm} \times 8 \mathrm{~mm}$ の摩擦面となる摩耗試験片を作製した。

摩耗試験は焼入れ，焼戻ししたダイス鋼 $(\mathrm{SKD}-11, \mathrm{Hv}$ $=860)$ を相手材とする葉山式摩耗試験機を用い, 乾燥摩耗 試験した. 接触圧力は $p=0.4 \mathrm{MPa}$ とし, 摩擦距離 $200 \mathrm{~m}$ 毎の試験片の摩耗体積を測定し, 比摩耗量を求めた. その 他の摩耗試験条件, 試験方法の詳細については既報 ${ }^{(2)(3)}$ と 同じである.

\section{III. 実験結果および考察}

\section{1. 摩耗に及ぼす素地珪素量の影響}

Fig. 2 と Fig. 3 は焼結/熱間押出し法で製造した種々の 珪素量の無黒鉛合金 $(\mathrm{Gr}=0 \%)$ の押出し方向に平行な断面 $\left(\theta=0^{\circ}\right)$ と種々の珪素量の Al-Si 合金の砂型鋳物および 金型鋳物における比摩耗量とすべり速度の関係を示す．焼

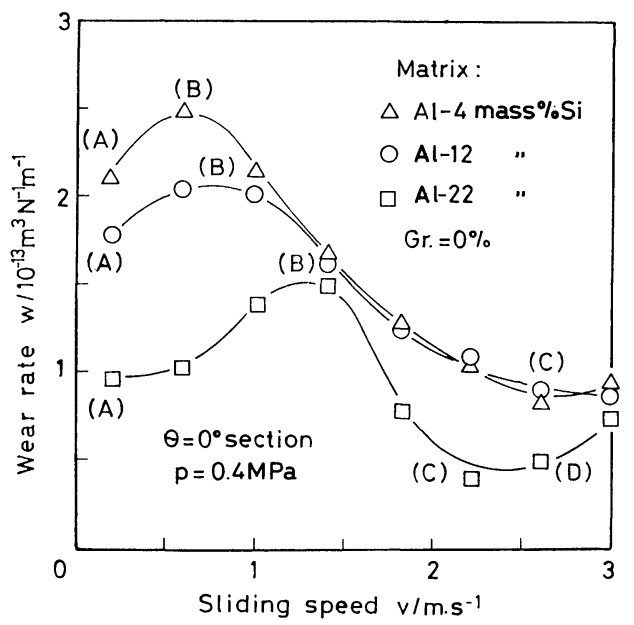

Fig.2 Changes in wear rate with sliding speed in the non-dispersed Al-Si alloys prepared by the sintering/hot-extruding process. 


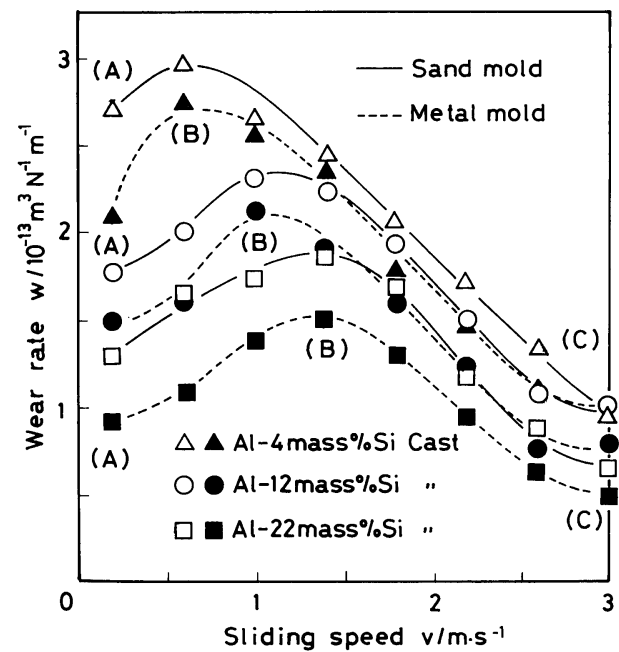

Fig.3 Changes in wear rate with sliding speed in the Al-Si alloys prepared by casting.

結/熱間押出しした無黒鉛合金では，すべり速度の上昇(図 中 $\mathrm{A} \sim \mathrm{B})$ によむなう比摩耗量の増加が低珪素量の合金ほ ど大きくなり，低すべり速度 $(\mathrm{B})$ で極大值に達した。また， すべり速度がさらに上昇 $(\mathrm{B} \sim \mathrm{C}) し て$, 比摩耗量が低下す る傾向がいずれの珪素量の無黒鉛合金にも見られ，そのす べり速度域は高速度側 $(\mathrm{C})$ まで拡大して, 比摩耗量は極小 值になった．Al-22 mass\%Si 合金の場合，比摩耗量の極 小值は小さいが，さらに高すべり速度域 $(\mathrm{C} \sim \mathrm{D})$ で，比摩 耗量がふたたび増加する傾向が認められた。

砂型扔よび金型 $\mathrm{Al}-\mathrm{Si}$ 合金鋳物の場合，すべり速度に よる比摩耗量の変化の傾向は，いずれの珪素量の鋳物之も, 焼結/熱間押出しした無黒鉛合金の場合と同様，比摩耗量 の增加するすべり速度域 $(A \sim B)$ と減少するすべり速度域 (B〜C) に区分され，比摩耗量が極大値となるすべり速度 $(B)$ が見られた．比摩耗量の極大值は高珪素量の合金ほど小さ く, 高すべり速度で生じた. しかし $(\mathrm{B} \sim \mathrm{C})$ 域における比 摩耗量の減少の度合いは，いずれの珪素量の合金すほぼ同 じであった。

軟質金属が摩擦されたとき，その真実接触部に相手材と 凝着が生じ，prowとなって成長する ${ }^{(12)(13)}$ 。乙の prow が破壊, 脱落する過程では比摩耗量は增加し, 脱落するて となく摩擦面に停留し，加工硬化した prow が硬質層を 形成すれば，比摩耗量は低下するとされている(14)。した がって比摩耗量はすべり速度の上昇ととあに増加し，ある すべり速度(B)で極大值となるが，てのすべり速度のとて ろで摩耗機構が変移する．珪素相のような硬い粒子が存在 すれば prowの成長は抑制されるので，高珪素量の合金 ほど比摩耗量の增加は小さく, また, prow ととあに珪素 粒子屯硬質層形成に加わるので, 比摩耗量の極大值は小さ くなり，そのすべり速度 $(\mathrm{B})$ が高速度側に移行したあのと 考えられる.

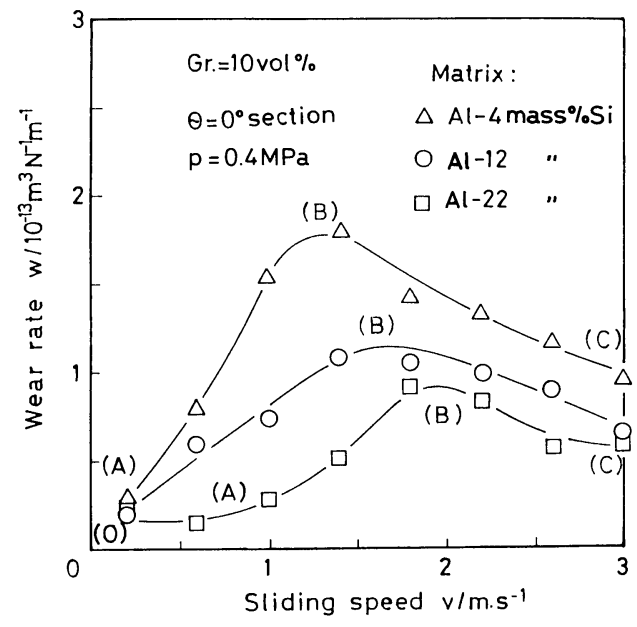

Fig.4 Changes in wear rate with sliding speed in the 10 vol\% graphite-dispersed alloys prepared by the sintering/hot-extruding process.

Fig.4 亿焼結/熱間押出しによって製造した種々の珪素 量の素地加ら成る $10 \mathrm{vol} \%$ 黒鉛分散合金の押出し方向に 平行な断面 $\left(\theta=0^{\circ}\right)$ に抢ける比摩耗量とすべり速度の関係 を示す．Al-22 mass\%Si 合金の素地の場合，低すべり速 度域 $(\mathrm{O} \sim \mathrm{A})$ で比摩耗量が非常に小さくなることが認めら れた．いずれの素地の合金もすべり速度の上昇 $(A \sim B) に$ とあない，比摩耗量は增加するが，その度合は無黒鉛合金 と比較すると小さく，比摩耗量の極大値む低い．素地の珪 素量が増すと, 比摩耗量の極大值は小さくなり，そのすべ り速度 (B)は高速度側に移行する。さらに高すべり速度域 (B〜C)では，いずれの珪素量の素地の場合あ比摩耗量の 低下が生じ，その度合はほぼ同じであった．比摩耗量の極 小值は実験した最高すべり速度 $(V=3.0 \mathrm{~m} / \mathrm{s})$ においてあ明 らかでなく，さらに高すべり速度であるととが予想された。

粉末押出し後再溶解した $10 \mathrm{vol} \%$ 黒鉛分散合金の比摩 耗量とすべり速度の関係を Fig.5亿示した。すべり速度 にともなう比摩耗量の増加抢よび減少の傾向は焼結/熱間 押出しした黒鉛分散合金と同様で，それらのすべり速度範 囲むほぼ同じであった．比摩耗量はいずれのすべり速度に 扔いても焼結/熱間押出しした合金より約 $(3 \sim 5) \times 10^{-14}$ $\mathrm{m}^{3} \mathrm{~N}^{-1} \mathrm{~m}^{-1}$ 程度高い値であった. そして高すべり速度に なると, 比摩耗量はふたたび増加し，低比摩耗量となるす べり速度域 $(\mathrm{C} \sim \mathrm{D})$ が認められた。

黒鉛分散合金の場合む, 素地の真実接触部のとてろに prow を形成するてとが考えられる．そしてすべり速度が 上昇するにしたがって, prow の成長, 脱落過程が頻発し, 比摩耗量が増加するあの之思わ机る。しかし黒鉛粒子が摩 擦面に存在しているので, 摩擦力を軽減し, 凝着も防止さ れ，prow の生成，成長は抑制する.したがって黒鉛分散 合金の $(\mathrm{A} \sim \mathrm{B})$ すべり速度域での比摩耗量の増加が無黒鉛 合金より小さくなったあのと思われる.さらにすべり速度 


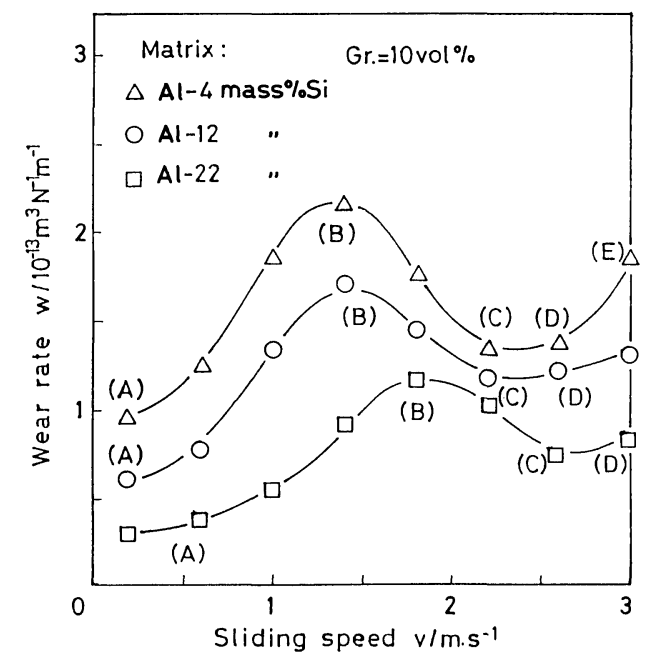

Fig.5 Changes in wear rate with sliding speed in the 10 vol\% graphite-dispersed alloys prepared by the re-melting process.

が上昇しても，摩擦面には破壊された prow の小塊や酸 化物粒子ととあに黒鉛粒子あ混在するので，乙れが硬質層 を相手材によって取り去られることを防止するむのと思わ れる.

そこで，焼結/熱間押出し法で製造した 3 種類の珪素量 の Al-Si 合金を素地とする無黒鉛合金と $10 \mathrm{vol} \%$ 黒鉛分 散合金について，比摩耗量が極大值となる摩擦条件で，3.0 $\mathrm{km}$ まで摩擦した摩耗面を SEM 観察した。その結果を Fig.6に示す.いずれの合金む平滑な面となっていて，そ の面上には摩擦方向に微細な擦傷痕が形成している.擦傷 痕は粒子状面の部分 (Fig.6の A 点)や摩耗粒子が脱落し たと思われるくぼみ部分 (Fig.6の B 点)あるいは黒鉛の 部分 (Fig.6の C 点)で中断されていて，その擦傷痕の長
さは黒鉛分散合金の方が，また高珪素量の素地の合金の方 が短い，摩擦面上の擦傷痕は prow の成長過程で形成す るむので(14)，prow が大きく成長するほどその長さは長 くなる．粒子状面は prow が成長するととなく破壊し， 小塊状となって摩擦面に停留して形成したものと思われる。 それ故，高珪素量の無黒鉛合金打よび黒鉛分散合金では prowの成長が小さく，(A〜B)のすべり速度域における 比摩耗量の増加が小さくなり, 比摩耗量の極大値屯低くなっ たものと思われる．また prow が高すべり速度まで脱落 するととなく粒子状面となって摩擦面に停留するのであれ ば， $(\mathrm{B} \sim \mathrm{C})$ 域の比摩耗量の低下が高すべり速度側まで拡 大したあのと思われる。

無黒鉛合金と $10 \mathrm{vol} \%$ 黒鉛分散合金について，比摩耗 量が極小值となるすべり速度 $(C)$ で $3.0 \mathrm{~km}$ まで摩擦した 後の摩耗面を SEM 観察した. Fig.7亿その結果を比較し て示す．ただし，黒鉛分散合金の場合，比摩耗量が極小値 に至っていないので, 実験した最高すべり速度 $(V=3.0 \mathrm{~m} / \mathrm{s})$ の時点での摩耗面とした．無黒鉛合金の場合，いずれの珪 素量の合金も摩耗面は大きく塑性流動し，深い擦傷痕を形 成していた。Al-4 mass\% Si 合金には成長した prow が 相手材から離脱し, 擦傷痕底に埋没して, 摩擦面に停留し ているとてろむ見られた (Fig.7の A 点).すべり速度の 上昇によって素地が軟化すると, 塑性流動し, 摩擦面は平 滑化され，また prow は圧しつぶされ，偏平状となって 停留するようになるので, 摩擦面に薄い表面層が形成する. $\mathrm{Al}-12$ mass\% $\mathrm{Si}$ 合金には，乙の表面層が剥離した跡と思 われるところあ見られた(Fig.7 の B 点). Al- 22 mass $\% \mathrm{Si}$ 合金の場合の摩耗面は平滑面が広く, 表面層が摩耗粒子と なって剥離した痕跡は小さく, 浅いものであった。乙れは 高珪素量の素地ほど, 硬く, 薄層化した表面層が形成す ると考えられ，乙のため高珪素量の素地の合金ほど，比摩 耗量の極小值が低くなったものと思われる.

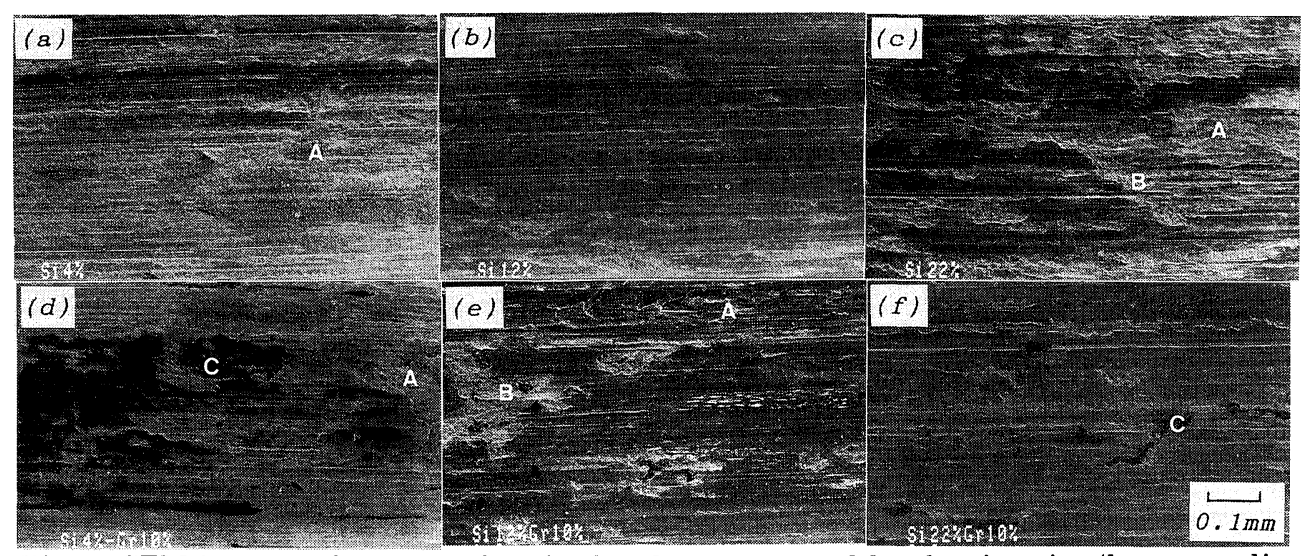

Fig.6 SEM images of worn surface in the alloys prepared by the sintering/hot-extruding process ; sliding surface of $\theta=0^{\circ}$ section, (a) Al- $4 \mathrm{mass} \% \mathrm{Si}, V=0.6 \mathrm{~m} / \mathrm{s}$, (b) Al-12 mass $\% \mathrm{Si}$, $V=1.0 \mathrm{~m} / \mathrm{s}$, (c) Al- $22 \mathrm{mass} \% \mathrm{Si}, V=1.4 \mathrm{~m} / \mathrm{s}$, (d) Al- $4 \mathrm{mass} \% \mathrm{Si}(\mathrm{Gr}=10 \mathrm{vol} \%), V=1.4 \mathrm{~m} / \mathrm{s}$, (e) $\mathrm{Al}-12$ mass $\% \mathrm{Si}(\mathrm{Gr}=10 \mathrm{vol} \%), V=1.8 \mathrm{~m} / \mathrm{s}$, (f) $\mathrm{Al}-22 \mathrm{mass} \% \mathrm{Si}(V=10 \mathrm{vol} \%), V=2.2 \mathrm{~m} / \mathrm{s}$; contacting pressure $p=0.4 \mathrm{MPa}$, sliding distance $L=3 \mathrm{~km}$. 


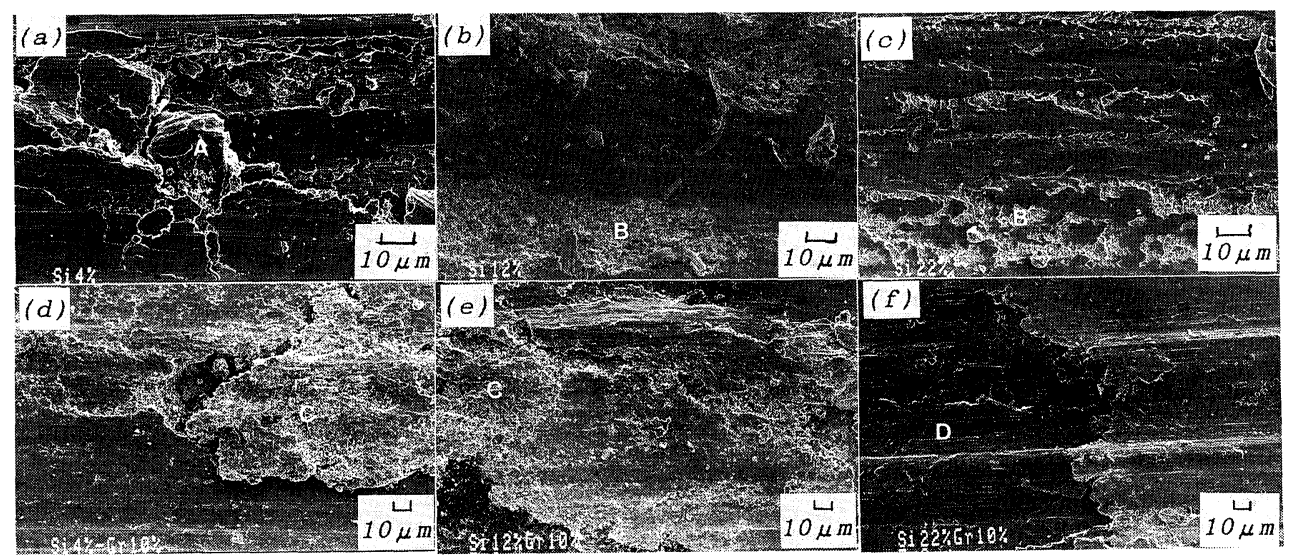

Fig.7 SEM images of worn surface in the alloys prepared by the sintering/hot-extruding process, (a) Al- 4 mass $\% \mathrm{Si}$, (b) Al-12 mass $\% \mathrm{Si}$, (c) Al-22 mass $\% \mathrm{Si}$ at $V=2.2 \mathrm{~m} / \mathrm{s}$ and (d) Al4 mass $\% \mathrm{Si}(\mathrm{Gr}=10$ vol $\%)$, (e) Al-12 mass $\% \mathrm{Si}(\mathrm{Gr}=10$ vol $\%)$, (f) Al- 22 mass $\% \mathrm{Si}(\mathrm{Gr}=10$ vol\%) at $V=3.0 \mathrm{~m}$ s. ; $\theta=0^{\circ}$ section, $p=0.4 \mathrm{MPa}, L=3 \mathrm{~km}$.

黒鉛分散合金む同様な摩耗面であるが，擦傷痕はさらに 細かく刻まれている。成長した prowああるが，それは 微細な粒子が集合し, 固化したものであって,さらに圧し つぶされて平滑面となっている(Fig.7の C 点). 高すべり 速度になっても，黒鉛粒子が分散していれば，相手材との 凝着を防ぐので, これらの摩耗面は維持され, 低比摩耗量 となったと考えられる.特に，Al-22 mass\% Si 素地の合 金では, prow の成長は小さく, 黒鉛粒子がそのまま露出 し(Fig.7の D点)，平滑な摩耗面を形成している．てれ らの表面層が破壊し, 脱落するのは,さらに高すべり速度 となることが予想される.

\section{2. 摩耗に及ぼす黒鉛量の影響}

Fig. 8 は Al-12 mass\% Si 合金の素地に種々の量の黒

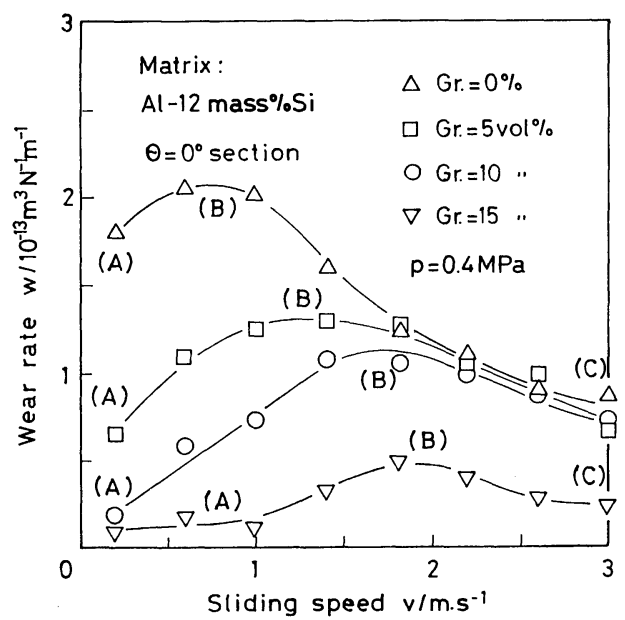

Fig.8 Changes in wear rate with sliding speed in the $\mathrm{Al}-12$ mass $\% \mathrm{Si}$ alloy containing various amount of graphite prepared by the sintering/ hot-extruding process.
鉛粒子が分散する合金の押出し方向に平行な断面 $\left(\theta=0^{\circ}\right)$ について，比摩耗量とすべり速度の関係を示す．黒鉛量が 増すにしたがって，(A〜B)のすべり速度域での比摩耗量 の増加の度合は減少する．そして高黒鉛量の合金ほど比摩 耗量の極大值は小さく，それに達するすべり速度(B)は高 速度側へ移行した．すべり速度がさらに上昇すると $(B \sim C)$, 比摩耗量は減少するが, 比摩耗量の減少の度合は黒鉛量に よってあまり変化しなかった，それ故，黒鉛粒子の分散は $(\mathrm{B} \sim \mathrm{C})$ のすべり速度域で生ずる摩耗より $(\mathrm{A} \sim \mathrm{B})$ 域に扔 ける摩耗に対して大きな効果を示した。てれは， $(\mathrm{A} \sim \mathrm{B})$ のすべり速度域での摩耗が, 素地の真実接触部における prow の形成，成長そして破壊によるあのと考えられるの で, 黒鉛粒子が潤滑効果となって, 相手材への凝着を防止 するため, (A〜B)のすべり速度域における比摩耗量の増 加を抑制する効果となったものと思われる. $(\mathrm{B} \sim \mathrm{C})$ のす べり速度域では, 摩擦面に加工硬化した prow や珪素粒 子が停留し, 硬化層が形成され, 比摩耗量は減少する。し たがっててのような比摩耗量の減少は素地中の黒鉛量に影 響されることなく，ほぼ一定の度合で減少するあのと思わ れる.

相手材への凝着状態を調べるために，摩擦前後の相手材 リングの摩擦面形状を測定した. Fig.9 は Al-12 mass\% Si 合金の素地に種々の黒鉛量を分散した合金について, 比摩 耗量が極大值となる速度で $3.0 \mathrm{~km}$ まで摩擦する前後の相 手材リングの表面形状を示す．無黒鉛合金を摩擦した場合， 相手材の摩擦面の随所に突起したところが見られた。 また， 深い溝となっているとてろああり, prowが疑着し，相手 材リングとの界面のとてろで破壊して脱落した跡か, ある いは硬化した prowによって受けた切削傷痕と思われる ところも観察された． $5 \mathrm{vol} \%$ 黒鉛分散合金では，僅かな 凝着打よび傷痕が観察されるが，黒鉛量が $10 \mathrm{vol} \%$ 以上 の合金であれば，合金の凝着は少なく，また相手材の摩擦 
面を損傷することも減少した。

Fig. 10 は無黒鉛合金と $10 \mathrm{vol} \%$ 黒鉛分散合金を，比摩 耗量が極大值となるすべり速度で $3.0 \mathrm{~km}$ まで摩擦したと

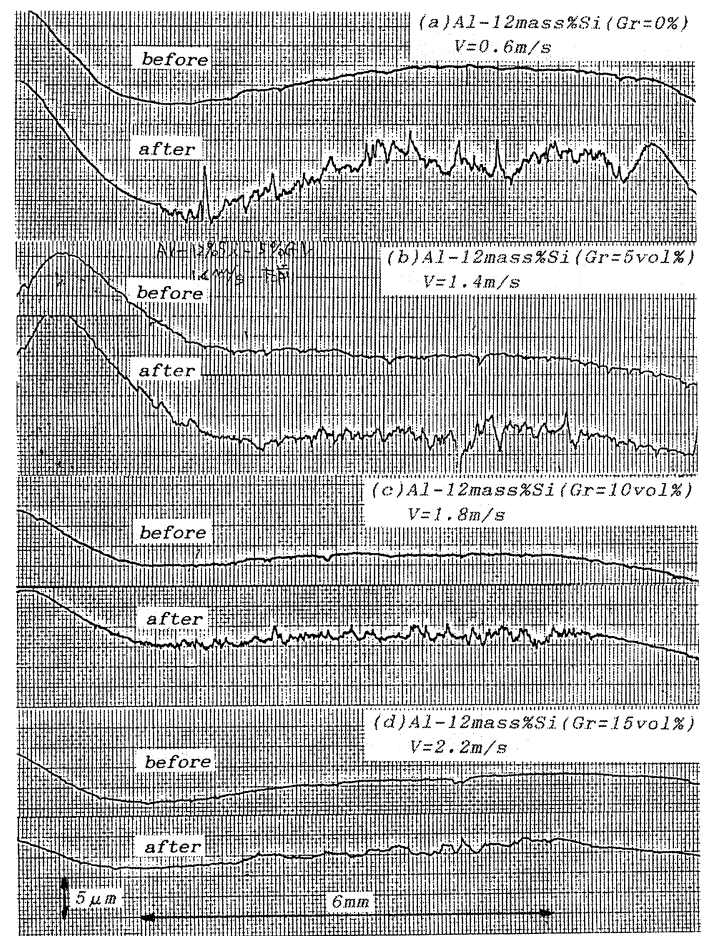

Fig.9 Cross-sectional profiles of hardened steel ring before and after sliding against the graphite-dispersed alloys prepared by the sintering/ hot-extruding process ; $\theta=0^{\circ}$ section, $p=0.4 \mathrm{MPa}$, $L=3 \mathrm{~km}$.
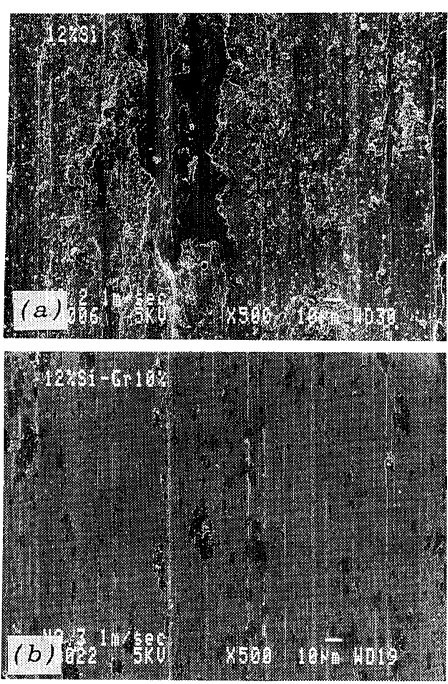

Fig.10 SEM images of the hardened steel ring in after sliding against (a) the non-dispersed Al-12 mass $\% \mathrm{Si}$ alloy and (b) 10 vol\% graphite-dispersed Al-12 mass $\% \mathrm{Si}$ alloy prepared by the sintering/ hot-extruding process; $\theta=0^{\circ}$ section, $p=0.4 \mathrm{MPa}$, $L=3 \mathrm{~km}$.
きの相手材リングの摩擦面の SEM 像を示す. 無黒鉛合金 で摩擦した相手材の摩擦面には，合金がうろこ状に凝着し ている.さらに摩擦方向に深い切削傷も観察された。乙れ に対し，10 vol\% 黒鉛分散合金を摩擦した相手面には，微 細な切削傷痕む見られるが，合金の凝着は非常に少なく， 黒鉛粒子が潤滑作用し，合金の凝着を防止することが確認 できた。

\section{3. 摩耗に及ぼす摩擦方向の影響}

焼結/熱間押出し法によって製造した黒鉛分散合金の黒 鉛粒子は押出し方向に伸長して配列している. その上, 素 地の共晶組織の珪素相屯押出し方向に整列した針状相になっ ている. したがって，押出し方向によって合金の摩耗特性 が変化することが考えられる. そこで押出し方向に対する 種々の角度 $(\theta)$ の摩擦面について摩耗特性を調べた. Fig.11 と Fig. 12 に Al-12 mass\% Si 合金を素地とする無黒鉛合 金と $10 \mathrm{vol} \%$ 黑鉛分散合金について, $\theta=0^{\circ}, 45^{\circ}, 90^{\circ}$ お よび $135^{\circ}$ 断面の比摩耗量とすべり速度の関係を示す. 無 黒鉛合金の場合, $(\mathrm{A} \sim \mathrm{B})$ のすべり速度域では, $\theta=0^{\circ}$ 断 面に掞いて比摩耗量の増加および極大值が最も大きく, $\theta$ が大きくなるにしたがってそれらは小さくなる．てれは， 素地の共晶組織が押出し方向に配向しているので, $\theta=0^{\circ}$ 断面を摩擦する場合が最す小さいせん断力で prow が摩 擦方向に成長でき, 多くの摩耗粒子を生成するようになっ て比摩耗量が最あ大きくなったものと思われる. しかし比 摩耗量の極大值となる $(\mathrm{B})$ のすべり速度は $\theta$ によって変化 しなかった．すべり速度域が $(\mathrm{B} \sim \mathrm{C})$ の範囲では, いずれ の断面を摩擦した場合む比摩耗量はほぼ同様に低下した. すべり速度が上昇し，摩擦熱によって素地が軟化すると， いずれの断面の摩擦においても prow や酸化物粒子の停

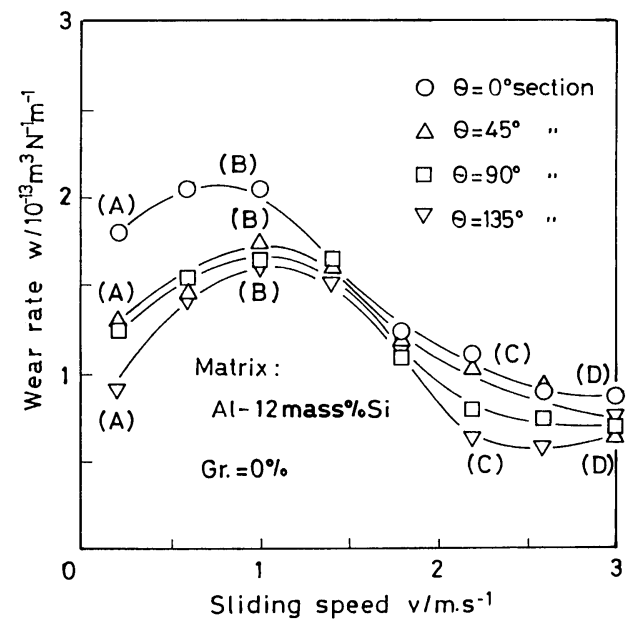

Fig.11 Changes in wear rate with sliding speed on sliding surface with various angles to extruding direction in the Al-12 mass $\% \mathrm{Si}$ alloys prepared by the sintering/hot-extruding process. 


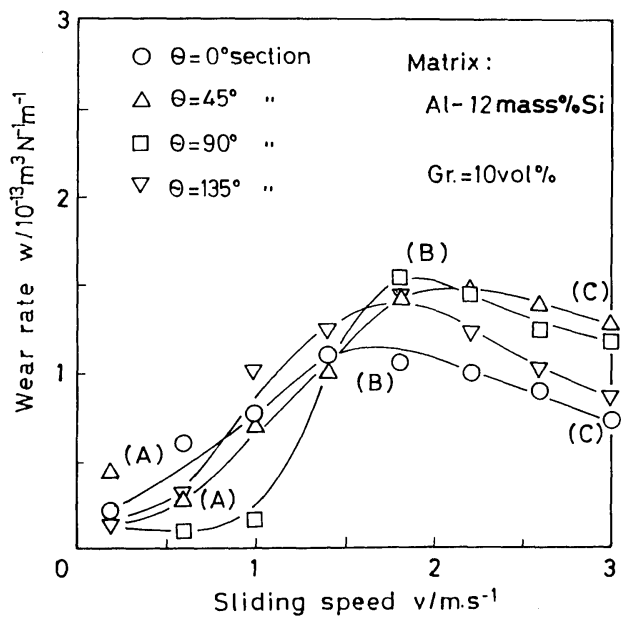

Fig.12 Changes in wear rate with sliding speed on sliding surface with various angles to extruding direction in the $\mathrm{Al}-12$ mass $\% \mathrm{Si}$ alloy dispersed 10 vol\% graphite particles.

留が生じ易くなるので，同様な傾向の比摩耗量の低下となっ たものと思われる。

Al-12 mass\% Si 合金を素地とする 10 vol\% 黒鉛分散 合金では，低比摩耗量となる $(\mathrm{O} \sim \mathrm{A})$ のすべり速度域およ び比摩耗量が増加し極大值となるすべり速度域 $(\mathrm{A} \sim \mathrm{B})$ の $\theta$ の方向による変化は僅かであった，それらのすべり速度 域は $\theta=0^{\circ}$ 断面の摩擦のとき, 最む低速度側であり, $\theta=90^{\circ}$ 断面の摩擦が最む高いすべり速度であった。しかし比摩耗 量の極大值の大きさ，あるいは $(\mathrm{B} \sim \mathrm{C})$ 速度域における比 摩耗量の大きさは $\theta=0^{\circ}$ 断面が最む小さく, $\theta$ が大きい断
面ほど大きくなった。

$(\mathrm{O} \sim \mathrm{A})$ のすべり速度域の $V=0.6 \mathrm{~m} / \mathrm{s}$ と $(\mathrm{B} \sim \mathrm{C})$ 域の $V$ $=3.0 \mathrm{~m} / \mathrm{s}$ のすべり速度で $3.0 \mathrm{~km}$ まで摩擦した摩耗面と それに垂直な電解研磨面の SEM 観察結果を Fig. 13 亿示 す．低すべり速度のとき，摩耗面は擦傷痕の少ない平滑な 面であった。そして prowが破壊して形成した微細な粒 子が集積して平滑面上あるいは黒鉛粒子上に停留している が(Fig.13の A 点)，それらは塊状となって象がんしてい た．素地相の塑性流動は少なく，黒鉛粒子の隱ぺいはほ んよ゙なされていない(Fig.13のB点)．また露出した黒鉛 粒子む表面部のとてろで僅かに流動していて(Fig.13の C 点)，黒鉛粒子が潤滑作用しているてとが推測できた。

高すべり速度となって素地が軟化すると, prowが成長 するようになる。しかし素地が摩擦方向への prow の成 長を抑制するような共晶組織となっているため, 摩耗面は 平滑でなく，樑く，短い擦傷痕が形成している．また素地 の塑性流動が小さく(Fig.13の D 点), 黒鉛粒子は隠ぺ されることはないので，黒鉛粒子は広い面積で露出するこ とになる(Fig.13の E 点).

黒鉛粒子が分散して潤滑作用し，相手材との凝着を防止 するととによって, prow の生成, 成長を抑制する効果は, 黒鉛の層面が配向している $\theta=0^{\circ}$ 断面の場合が最も高いて とが純アルミニウムを素地とする粉末押出し合金で認めら れた ${ }^{(2)}$. 一方, 前述した無黒鉛合金のように, $\theta=0^{\circ}$ 断面 では摩擦方向に共晶珪素相が配向していて, prow は成長 し易く，比摩耗量が大きい。したがって prow の成長, 破壊による摩耗に対して, 共晶珪素相之黒鉛粒子の配向性 の効果が異なり, それらが相乗して影響するので, 摩擦挙 動が複雑に変化したものと思われる.

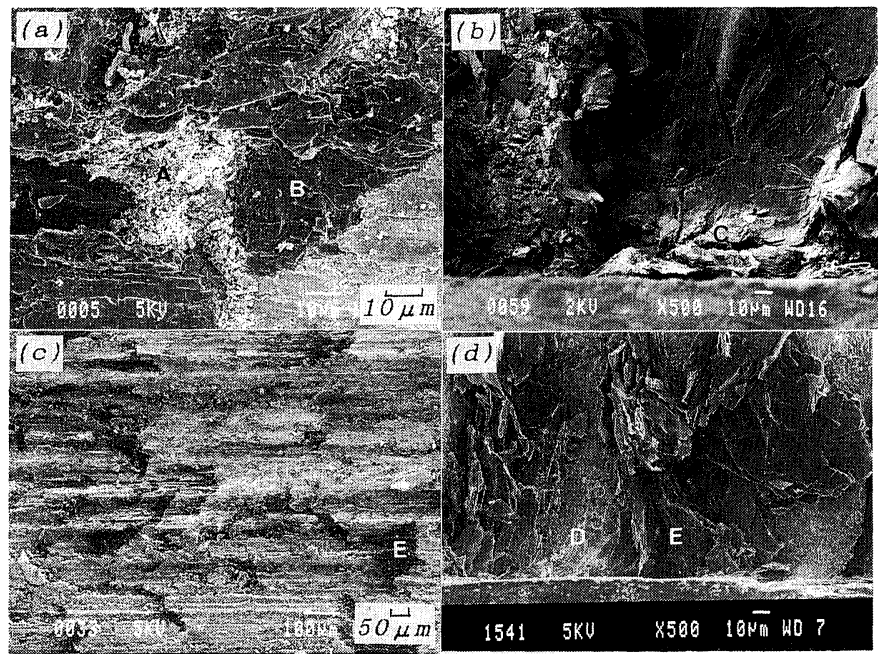

Fig.13 SEM images of (a), (c) worn surface and (b), (d) cross section in the Al-12 mass $\%$ Si alloy containing 10 vol\% graphite prepared by the sintering/hot-extruding process, (a), (b) at $V=0.6 \mathrm{~m} / \mathrm{s}$ and (c), (d) at $V=3.0 \mathrm{~m} / \mathrm{s} ; \theta=90^{\circ}$ section, $p=0.4$ $\mathrm{MPa}, L=3 \mathrm{~km}$.

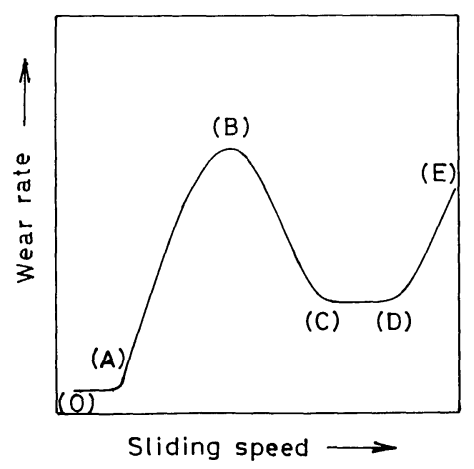

Fig.14 Schematic relationship between wear rate and sliding speed in the graphite-dispersed aluminum alloys. 


\section{IV. まと め}

アルミニウム，珪素抢よび黒鉛の混合圧粉体を，素地に 液相が生成する温度で焼結しつつ熱間押出しする複合加工 法で, $\mathrm{Al}-\mathrm{Si}$ 合金の素地に黒鉛粒子が分散する合金を製 造し, その摩耗特性を調べた. また通常の Al-Si 合金鋳 物や混合圧粉体を粉末押出し後, 再溶解した合金について あ調べた。その結果，いずれの合金も Fig.14に示すよう に, すべり速度にとすない比摩耗量の変化が生じ, その際 の摩耗機構が変化することが推測されたすすなわち，(O〜A) 域は摩擦面が平滑化され, 比摩耗量が非常に低い速度域, (A〜B)域は摩擦面の真実接触部に prow が生成し, 成長, 破壊して摩耗する速度域で，すべり速度の上昇にとむない prow の生成 - 破壊過程が頻発するため比摩耗量が増加す る，(B〜C)域は prow が成長し，加工硬化して破壊する か, あるいは酸化して微細な粒子となって摩擦面に停留し, 平滑な硬化表面層を形成するため比摩耗量が減少する速度 域，(C〜D)域は硬化表面層が保持されて低比摩耗量とな る速度域，(D〜E)域は硬化表面層が除去されて溶着が生 じ，とあがね状態となって比摩耗量が急増する速度域であ る.乙のような摩耗傾向は, 既報 ${ }^{(2)(3)}$ のように, 粉末押出 し法によって製造した純アルミニウム粉および Al-Si 混 合粉を素地とする黒鉛分散合金にも見られた。そてで，粉 末押出し法で製造した合金の摩耗試験結果す含め，各す心 り速度域における摩耗挙動に及ぼす珪素相，黒鉛粒子分散 の影響を比較し，考察すると，

(1) すべり速度 $(\mathrm{O} \sim \mathrm{A})$ 域は微細な珪素相をあつ素地に 黒鉛粒子を分散させるととにより拡大する.

（2）(A〜B)域における比摩耗量の増加は素地を微細珪 素相あるいは微細で方向性のある層状珪素相とするか, ま たは高珪素量の素地とし，乙れに黒鉛粒子を分散させるこ
とによって抑制でき, $(\mathrm{A} \sim \mathrm{B})$ 域から $(\mathrm{B} \sim \mathrm{C})$ 域の摩耗機 構の変換によって生じる比摩耗量の極大值は高すべり速度 側に移行する。

（3）（B～C)域での比摩耗量の減少に対し, 素地の珪素 量や黒鉛量, 分散形態の影響は小さいが, $(\mathrm{C} \sim \mathrm{D})$ 域は軟 質な素地の方が広い. しかし(D〜E)域の溶着摩耗が生じ 易い.

（4）軟質な素地に黒鉛粒子が分散すると，（C～D) 域は 狭く, $(\mathrm{D} \sim \mathrm{E})$ 域の比摩耗量は大きくなるが, 素地を強化 することによっててれらは抑止できる.

\section{文献}

（1）湯浅栄二, 師岡利政: 塑性之加工, 24(1983), 751 .

（2）湯浅栄二, 師岡利政, 葉山房夫 : 日本金属学会誌, $49(1985), 981$.

（3）湯浅栄二, 師岡利政, 葉山房夫 : 日本金属学会誌, 50(1986), 1032 .

(4) B.C.Pai and P.K.Rohatgi : Trans. Indian Inst. Metals, 27(1974), 97.

(5) M. K. Surappa and P.K. Rohatgi : Metals Tech.,5(1978), 358.

(6) A.F.Badia and P.K.Rohatgi : AFS, Trans., 77 (1969), 402.

(7) B. C. Pai, P. K. Rohatgi and S. Venkatesh : Wear, (1974), 117.

（8）諏訪正輝, 小室勝博, 添野 浩: 日本金属学会誌, 40(1976), 1074.

(9) P. K. Rohatgi and B. C. Pai : Wear, 59(1980), 323.

(10) R. R. Soni, N. K. Jain, T. V. Rajan and D. Kumar: Trans. Indian Inst. Metals, 35(1982), 469.

（11）湯浅栄二, 師岡利政，葉山房夫 : 塑性と加工, 27 (1986), 1203.

(12) M.Cocks : J. Appl. Phys., 33(1962), 2152.

（13）塚本雄二, 笹口裕昭, 葉山房夫 : 日本金属学会誌, $44(1980), 68$.

（14）葉山房夫: 鋳研報告, No.42(1986), 1. 